\title{
COMPARATIVE ANALYSIS OF ENERGY SUPPLY METHODS FOR AN INDIVIDUAL RESIDENTIAL BUILDING
}

\author{
*Ikem, A. Ikem ${ }^{1}$, Matthew, I. Ibeh ${ }^{2}$, Paschal, A. Ubi ${ }^{3}$, Saviour, E. Ofem ${ }^{4}$, Assam, T. Assam ${ }^{5}$ \\ ${ }^{1}$ (Department of Mechanical Engineering, Faculty of Engineering, \\ Cross River University of Technology, Nigeria), \\ ${ }^{2}$ (Department of Mechanical Engineering, Faculty of Engineering, \\ Michael Okpara University of Agriculture, Umudike, Nigeria), \\ ${ }^{3}$ (Department of Mechanical Engineering, Faculty of Engineering, \\ University of Calabar, Nigeria), \\ ${ }^{4}$ (Department of Mechanical Engineering, Faculty of Engineering, \\ Cross River University of Technology, Nigeria), \\ ${ }^{5}$ (Department of Mechanical Engineering, Faculty of Engineering, \\ Cross River University of Technology, Nigeria) \\ E-mail: azors9kee@yahoo.com*
}

\begin{abstract}
Electrical power supply is the pivot and wheel of development of any economy particularly when the supply is usually cheap, constant and enough to run all factory or industrial equipment and home appliances. When this not so, the government, organizations or individual must find a cheaper way of supplying this energy to satisfy their needs. Hence, the search for cheap independent sources of energy was carried out to compare with that from the national grid. Diesel generator, wind power plant and solar power plants were compared to select which was more economically feasible to be employed.
\end{abstract}

Keywords : Electrical power, industrial equipment, diesel generator, solar plant, wind.

\section{Introduction}

Today, Nigeria's energy sector is characterized by an extremely high level of depreciation: the deterioration of power transmission lines in the Power Holding Company of Nigeria (PHCN) exceeds 30\%, of substations $50 \%$. Electricity losses in the networks grow every year and have already reached the double-digit threshold. Taking into account the fact that Nigerian power plants have an average efficiency of $\approx 30 \%$, the length of heat networks is limited by the size of the city due to high linear losses; for territories with a low density of energy consumers, for example, in low-rise buildings, the implementation of distributed energy becomes particularly important.

In conditions of impossibility of concentration of large investments for construction of large power stations, the construction of small ones proves to be more real and profitable, since it allows significantly reducing the volume of initial investments and the period of their return, reducing investment risk, and reducing the time for construction and commissioning of stations.

For remote and hard-to-reach areas, especially for the conditions of the states far away South of the Power Plant in KainjiDam, small independent power stations (SIPs) can be used, the efficiency of which is based on the lack of maintenance for decades.

\section{STUDY AREA}

Benue statein north central region of Nigeria lies between latitude $6^{0} 25^{\prime}$ and $8^{0} 8^{\prime} \mathrm{N}$ and longitude $7^{0} 47^{\prime}$ and $10^{\circ}$ 0 ' E. The entire country experiences majorly two seasons which are the dry and rainy seasons. In Benue state, the rainy season begins from April to October and dry season from November to March. The country lies between latitudes that receive enormous amount solar irradiance almost throughout the year. Benue state has the temperature range between $21-37^{\circ} \mathrm{C}$ in a year. 


\section{MATERIALS AND METHOD}

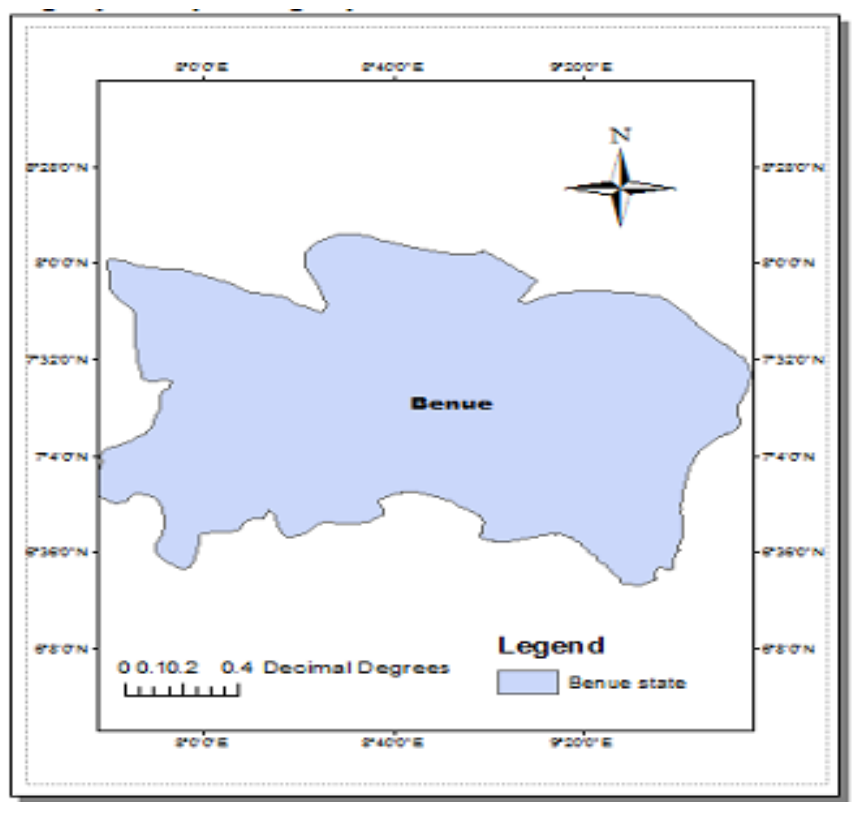

Figure 2.1: Map of the study area

A MATERIALS - Diesel generator, wind power plant and solar panels

This research work made use of data, which are gathered from market survey, technical data sheet used in past designs, installation, maintenance records of the equipment. The study location for this work and time was Makurdi, Benue State of Nigeria in, 2017. This work also made use Microsoft excel package analyze results.

B METHOD - Install each of the equipment, run each independently and compare the cost of each with the cost of using electricity from the national grid to see the feasibility of using any of them as cheaper independent source of power supply.

\section{Independent Power Supply Based On Diesel Generator}

All electric generators are classified into three-phase and single-phase according to the type of current produced. Such generators are running most home and business appliances. Three-phase devices are able to create an alternating voltage of 380 volts, while single phase, 220 volts with a frequency of $50 \mathrm{~Hz}$ [3].

There are three types of generators: diesel, gasoline and gas. From the economic point of view, it is advisable to operate the gas generator only in the area where there is a Central gas pipeline. Its size is quite bulky, and it is too demanding to the conditions of installation and operation. Thus, the main choice remains only between popular gasoline and diesel power generators.

The generator with gasoline consuming engine is compact and much cheaper than a diesel generator. Such an assembly is best suited as a source of emergency power, since it will be serviced periodically. In the long-term operation, its technical and economic performance is significantly reduced: due to limited power, the generator needs to be periodically stopped and cooled, in contrast to the diesel, which can work continuously for a long time [1].

The cost of generators based on gasoline engines depends on different parameters: the device of the unit, its power, the type of engine (two-, four-stroke), the volume of the engine cylinder, the amount of fuel consumed, the manufacturer and the country of manufacture. The price range is quite wide: from 75 thousand naira to $1,500,000$ million naira. Some, especially high-quality models, can cost even more.

Diesel generators, in comparison with gas, are more reliable and powerful, can serve as the only, Autonomous, independent sources of electricity with lower fuel costs.

The main division of diesel generators occurs depending on the number of engine revolutions: 1500 and 3000 $\mathrm{rpm}$, while generators with a small number of revolutions are not so overheated and are able to work without stopping for a long time. Also as advantages it is possible to note a big line of capacities, easily available fuel, and simplicity in operation, mobility and speed of start-up.

In comparison with generators on gasoline based engines, the price of diesel generators is higher and ranges from 500,000 thousand to 20 million naira (and higher), depending on the technical characteristics of the model, reliability, manufacturer and management. 
However, there are disadvantages: high fuel costs, strong noise, harmful emissions and short life in heavy modes. The use of a diesel engine makes it difficult to start at low temperatures, and therefore all diesel power plants and generators are initially equipped with an electric starter and a battery, which increases the initial weight and price of the unit. Also diesel generators are sensitive to the load. The optimal load range $50-75 \%$ of the nominal. Otherwise, the motor life of the diesel generator is significantly reduced and its service life is reduced [3].

Let's give a calculation of the economic feasibility of using diesel generators. Assume that with the minimum amount of power consumption, the power required for optimal operation of all electrical appliances connected to the network is equal to $13,878 \mathrm{~kW}$, the input voltage is $48 \mathrm{~V}$. It is necessary to select the generating equipment such that the total load on it leaves approximately $25 \%$ of the rated power. Accordingly, we choose a diesel generator SDMO with a capacity of $19.2 \mathrm{~kW}$, the characteristics of which are given in Table 1 .

Table 1: Technical characteristics of the diesel generator SDMO K27
\begin{tabular}{|l|l|}
\hline Model & Adriatic K27 \\
\hline Engine & Kohler KDI2504M \\
\hline Type of fuel & Diesel \\
\hline Power $(400 \mathrm{~V})$ & $19.2 \mathrm{~kW}$ \\
\hline Fuel consumption & $6.31 / \mathrm{h}$ \\
\hline Launching & Electric starter \\
\hline Fuel tank capacity & $50 \mathrm{l}$ \\
\hline Execution & Open \\
\hline The weight & $540 \mathrm{~kg}$ \\
\hline Dimensions & $1410 \times 720 \times 1080 \mathrm{~mm}$ \\
\hline
\end{tabular}

Determination of the cost of equipment acquisition, installation and commissioning of the diesel generator (DG) [1]:

Determination of the main types of costs:

(i) Cost of installation, $C_{\text {inst }}$

$\mathrm{C}_{\text {inst. }}=0.3 \times \mathrm{C}_{\mathrm{dg}}$

Where $\mathrm{C}_{\mathrm{dg}}$ - the cost of diesel generator;

(ii) Cost of design, $\mathrm{C}_{\text {design }}$

$\mathrm{C}_{\text {design }}=0.1 \times \mathrm{xC}_{\text {inst }}$.

Where $\mathrm{C}_{\text {inst. }} \quad$ - the cost of installation;

(iii) Cost of commissioning

$\mathrm{C}_{\text {com }}=0.04 \times \mathrm{xC}_{\mathrm{dg}}$

(iv) Total cost of acquisition, $\Sigma E q$

$\Sigma E q=\mathrm{dx} \mathrm{C}_{\mathrm{dg}}+\mathrm{C}_{\text {inst. }}+\mathrm{C}_{\text {design }}+\mathrm{C}_{\text {com. }}$

Where $\mathrm{d}$ - the quantity of DG;

$\mathrm{C}_{\mathrm{dg}}$ - Cost of diesel generator;

$\mathrm{C}_{\text {inst. }}$ - Cost of installation works;

$\mathrm{C}_{\text {design }}$ - Cost of design work;

$\mathrm{C}_{\text {com. }}$ - Cost of commissioning.

(v) Annual maintenance costs of DG will take $10 \%$ of its cost [1]:

Maintenance Cost, $\mathrm{C}_{\mathrm{mc}}$

$\mathrm{C}_{\mathrm{mc}}=0.1 \times \mathrm{C}_{\mathrm{dg}}$

(vi) Cost of diesel fuel, $F_{\text {cost }}$

$\mathrm{F}_{\text {cost }}=\mathrm{F}_{\text {cons }} \times \mathrm{F}_{\mathrm{p}} \times \mathrm{h} \times 365$,

Where $F_{p}$ - Fuel price, $\mathrm{N} / l$, which is equal to 174 (according to "NNPC" as at year 2016;

$\mathrm{F}_{\text {cons }}$ - Fuel consumption in DG is $6.2 \mathrm{l} / \mathrm{h}$.

(vii) The annual saving of funds due to the use of DG will be determined as follows [1]: 
(viii) Annual saving, $\Delta \Sigma S$

$\Delta \Sigma S=\mathrm{C}_{\mathrm{NEP}}-\mathrm{F}_{\text {cost }}-\mathrm{C}_{\mathrm{mc}}$

Where $\mathrm{C}_{\mathrm{NEP}}-$ Cost of electricity supplied by the grid; $\mathrm{F}_{\text {cost }}-$ Cost of diesel; $\mathrm{C}_{\mathrm{mc}}-$ Cost of maintenance.

\section{Independent power supply based on wind power plant}

Conversion of air flow energy into electricity is possible only in a certain range of wind speeds [9]. The minimum value of wind speed for the operation of a typical wind power plant is $3 \mathrm{~m} / \mathrm{s}$. The Masts of wind turbines, in addition, have a significant height and span of the rotor blades (usually from five and a half meters, respectively), which under certain conditions, can be a significant drawback. There are also multi-bladed wind turbines, with a minimum wind speed to start work at $1.5 \mathrm{~m} / \mathrm{s}$, but in the case of strong wind gusts, friction losses will be high [4].

Modern wind turbines, using the latest production technologies, are designed for a life of up to 20 years; the efficiency of most wind turbines is about $26 \%$.

In the temperate latitudes, the average wind speed at the surface of the Earth is usually $3-5 \mathrm{~m} / \mathrm{s}$, while at $15-25 \%$ of the time it decreases below the critical values (less than $2.5-3 \mathrm{~m} / \mathrm{s}$ ). Thus, in accordance with the climatic norm for such areas, the wind power plant can be used $75-85 \%$ of the time, but mainly at minimum levels of electricity generation. On the territory of Makurdi region the highest wind speed is observed in summer from July-August (up to $4.5 \mathrm{~m} / \mathrm{s}$ ), and the lowest is in winter from January-February which is about $1 \mathrm{~m} / \mathrm{s}$.

For Makurdi region during this period of study to provide electricity to consumers of the region, the wind generator "Sokol Air Vertical - $15 \mathrm{~kW}$ " was chosen, designed for regions with a reduced average annual wind speed, with a capacity of $15 \mathrm{~kW}$, an input voltage of $48 \mathrm{~V}$.

Let us determine the economic feasibility of using wind turbines. The structural cost, $\mathrm{C}_{\mathrm{wf}}$ associated with the installation of wind turbines is determined by the total cost of all wind turbines [1] and will be

\section{(i) Cost of the wind farm, $\mathrm{C}_{\mathrm{wf}}$}

$\mathrm{C}_{\mathrm{wf}}=\mathrm{nxN}$

Where $\mathrm{n}$ - Number of wind turbines; $\mathrm{N}$ - Cost of one wind farm.

(ii) Cost of electrical equipment, $\mathrm{C}_{\text {el.eq }}$

$\mathrm{C}_{\text {el.eq }}=\mathrm{C}_{i n v}+\mathrm{C}_{\text {batt }}$,

Where $\mathrm{C}_{\mathrm{inv}}$ and $\mathrm{C}_{\text {batt }}$ are the costs of the inverter and battery respectively. Selected battery series is Microart, traction armored $2 \mathrm{~V}, 960 \mathrm{Ah}$ (deep discharge); specifications are shown in table 1.

(iii) Cost of construction, $\mathbf{C}_{\text {const }}$

$\mathrm{C}_{\text {const }}=0.05 \times \mathrm{x}_{\mathrm{wf}}$

Where $\mathrm{C}_{\mathrm{wf}}$ - Cost of the wind farm

(iv) Cost of design, $C_{\text {design }}$

$\mathrm{C}_{\text {design }}=0.25 \mathrm{xC}_{\text {const }}$

Where $\mathrm{C}_{\text {const }}$ - Cost of construction

(v) Cost of commissioning, $\mathrm{C}_{\text {comm }}$

$\mathrm{C}_{\text {comm }}=0.03 \times \mathrm{C}_{\mathrm{wf}}$

Where $\mathrm{C}_{\mathrm{wf}}-$ Cost of wind farm

Total investment, $\phi_{i n v}$ in the wind power plant is

$\phi_{\text {inv }}=\mathrm{C}_{\mathrm{wf}}+\mathrm{C}_{\text {eleq }}+\mathrm{C}_{\text {const }}+\mathrm{C}_{\text {design }}+\mathrm{C}_{\text {comm }}$

Selected battery series is Microart, traction armored 2 V, 960 Ah (deep discharge); specifications are shown in table 2.

Table 2: Battery Specifications Microart [5]

\begin{tabular}{|l|c|}
\hline Product category & Battery traction, for independent and backup systems \\
\hline $\mathrm{U}$, volt & 2.0 \\
\hline Capacitance, $\mathrm{Ah}$ & 960 \\
\hline
\end{tabular}


Selected inverter map SIN Energy Pro 48V 6kW, specifications are shown in table $3[5,9]$.

Table 3: Technical characteristics of the MAP inverter SIN Energy Pro

\begin{tabular}{|l|c|}
\hline \multicolumn{1}{|c|}{ Product category } & Map SIN Energy Pro 48V \\
\hline Power, $\mathrm{kVA}$ & 6.00 \\
\hline Efficiency,\% & 96 \\
\hline $\mathrm{U}$, volt & 48.0 \\
\hline U OUT, volt & 220.00 \\
\hline$\sim$ Frequency, $\mathrm{Hz}$ & 50.0 \\
\hline$\sim$ Peak power, $\mathrm{kW}$ & 9.0 \\
\hline Maximum power, $\mathrm{kW}$ & 6.0 \\
\hline Rated power, $\mathrm{kW}$ & 4.0 \\
\hline Own consumption on xx, $\mathrm{W}$ & $14.4-24$ \\
\hline Recommended total battery capacity, Ah & 800 \\
\hline Min total battery capacity, Ah & 200 \\
\hline Max recommended capacity of acid batteries, Ah & 1700 \\
\hline Operating temperature range, $0 \mathrm{C}$ & $-25 \ldots .50$ \\
\hline Dimensions [VCG], cm & $21 \times 27$ x 51 \\
\hline Weight without package, kg & 30.10 \\
\hline
\end{tabular}

(vi) Payback period of wind turbines [1]:

$\tau=\frac{\phi_{\text {inv }}}{\Delta \Sigma S}$

Where $\phi_{\text {inv }}$ - investments for the purchase of equipment, installation, and commissioning;

$\Delta \Sigma S$ - Annual Savings through the use of wind turbines [1].

$\Delta \Sigma S=\mathrm{C}_{\mathrm{NEP}}-\mathrm{C}_{\mathrm{mc}}$

where $\mathrm{C}_{\mathrm{NEP}}$ - payment for energy resources supplied by the grid company, $\mathrm{C}_{\mathrm{yr}}$ - annual costs including the salary of maintenance personnel, and costs associated with ensuring the operation of equipment, taking into account depreciation charges and inflation [1].

$\mathrm{C}_{\mathrm{mc}}=0.05 \times \mathrm{C}_{\mathrm{wf}}$

(vii) The annual costs for the payment of electricity supplied to the establishment by a grid company [1]:

$\mathrm{C}_{\mathrm{NEP}}=\mathrm{P}_{\max } \times 365 \times \mathrm{C}_{e l}$

Where $C_{e l}$ - cost of electricity supplied to establishment by the grid company, ( $) / \mathrm{kWh}$ (for simplification of calculations we will use the prices for a one-rate/flat rate tariff) we will accept equal $\$ 14.24 \mathrm{k} / \mathrm{kWh}$ (according to the tariffs by the Power Holding Company of Nigeria (PHCN) the major electric power operating company since year 2016;

$\mathrm{P}_{\max }$ - Maximum power consumption, generated by an independent wind power station per day, $\mathrm{kW}$ [1].

\section{Independent power supply based on solar stations}

During the year, $10^{18} \mathrm{kWh}$ of solar energy comes to the Earth, just $2 \%$ of which is equivalent to the energy obtained from the combustion of $2 \times 10^{12}$ tons of conventional fuel. This value is comparable to the world fuel resources. So in the future, solar energy may well become the main source of electricity on Earth [6].

The solar radiation flux passing through a $1 \mathrm{~m}^{2}$ site, located perpendicular to the radiation flux at a distance of one astronomical unit from the center of the Sun (at the entrance to the earth's atmosphere), is $1367 \mathrm{~W} / \mathrm{m}^{2}$ (solar constant). Because of the absorption, as the atmospheric mass of the earth passes, the maximum solar radiation flux at sea level (at the equator) is $1020 \mathrm{~W} / \mathrm{m}^{2}$. The average value is considered to be $1000 \mathrm{~W} / \mathrm{m}^{2}[6]$.

These data are applicable to horizontal sites, but the solar panel can be placed vertically and at an arbitrary angle to the horizon, and, accordingly, to the Sun. At the same time, the angle at which the maximum level of insolation for different points is achieved is different and depends on the latitude. For example, for Makurdi it is $7.73^{0}$, for Damaturu- $11.74^{0}$, for Calabar- $4.97^{0}$, for Ikeja- $6.58^{0}$, for Enugu- $6.47^{0}$. In addition, the position of the battery can be altered so that it is constantly located in relation to the sun at an angle close to $90^{\circ}$, which allows a significant (1.5-1.8 times) increase in the converted energy. 
The advantage of solar panels is the ultimate design simplicity and the complete absence of moving parts, as a result - a small specific weight, simplicity, easy installation and minimum maintenance requirements during operation. Being flat elements of small thickness, they do not require the construction of individual bulky structures. Energy is generated immediately in the form of electricity from dawn to dusk, even in cloudy weather. The efficiency of solar energy receiver panels is about $22 \%$ [6]. The practical application of solar panels proves that their service life exceeds 20 years.

The actual average duration of sunshine per year in Makurdi is $84 \%$ of the possible duration. Long-term climatic data show that the average in Makurdi of 365 days there are 57 without sun. The greatest number falls on the winter-42 days, and in the summer only 2-3 days. The number of Sunny days per year may vary slightly.

A preliminary assessment of costs for installation and operation of solar power plants (SPP), the brand, quantity and cost of the equipment selected for the SPP are listed in table 4.

Table 4: Composition of the SPP

\begin{tabular}{|c|l|c|c|c|c|}
\hline S/№ & \multicolumn{1}{|c|}{ Name } & Make & Quantity & Cost Units, N. & Total (amount) \\
\hline 1 & Solar panel & $\begin{array}{c}\text { Exmork FSM-300P 300 watts } \\
\text { 24V Poly }\end{array}$ & 15 & 82,420 & $1,236,300$ \\
\hline 2 & Battery block & EnerSysPowerSafe 12V125F & 16 & 220,360 & $3,525,760$ \\
\hline 3 & Charge Controller & eTracer ET4415N & 1 & 160,000 & 160,000 \\
\hline 4 & Inverter & Expert 5000/48 & 1 & 295,000 & 295,000 \\
\hline 5 & Balance & Megaron BACT Pb-002-12-1000 & 4 & 75,000 & 300,000 \\
\hline \multicolumn{4}{|c|}{ Total, rubbles } & \multicolumn{2}{c|}{$4,717,060$} \\
\hline
\end{tabular}

Let's take the cost of one panelC $C_{n}$, as the base unit; the cost of all panels and other equipment are [2]:

(viii) Cost of total panels, $C_{t p}$

$\mathrm{C}_{\mathrm{tp}}=\mathrm{C}_{\mathrm{p}} \mathrm{x} n$

Where $\mathrm{n}$ is the number of panels [2]; $\mathrm{C}_{t p}$ - total cost of panels.

The cost of construction and installation works, depending on the location of solar panels, is $20 \%$ of the cost of equipment.

(viv) Cost of equipment, $\mathrm{C}_{\text {equip }}$

$\mathrm{C}_{\text {equip }}=\left\{\mathrm{C}_{\mathrm{tp}}+\mathrm{C}_{\mathrm{sp}}+0.2\left(\mathrm{C}_{\mathrm{tp}}+\mathrm{C}_{\mathrm{sp}}\right)\right\}$

Where $\mathrm{C}_{t p}$ - total cost of panels, $\mathrm{C}_{\mathrm{sp}}$-Cost of solar panel,

$\mathrm{C}_{\mathrm{sp}}=\left(\mathrm{C}_{\text {battp }}+\mathrm{C}_{\text {rock }}+\mathrm{C}_{k}+\mathrm{C}_{\text {inv }}\right)$

Where $\mathrm{C}_{\text {battp }}$ - Cost of a battery pack, $\mathrm{C}_{\text {rock }}$ - Cost of rocker; $\mathrm{C}_{\mathrm{k}}$ - Cost of the charge controller; $\mathrm{C}_{\text {inv }}-$ Cost of the inverter,N.

The cost of commissioning work - $5 \%$ of the cost of equipment (investment in the event) [2]:

(v) Cost of commission, $\mathrm{K}_{\text {com }}$

$K_{\text {com }}=\left(0.05 \times C_{\text {equip }}\right)$

(vi) Cost of installing solar power plants [2]:

$C_{\text {instn }}=\left(C_{\text {equip }}+K_{\text {com }}\right)$

(vii) Annual maintenance costs of the plant [2]:

$M_{\text {Tex.equip }}=0.2 \times\left(C_{\text {instn }} \times H_{A}\right) / T_{\text {serv }}$

Where $\mathrm{M}_{\text {Tex.equip }}$-Annual maintenance cost of equipment; $\mathrm{H}_{\mathrm{A}}$ - the annual rate of depreciation which is assumed to be $20 \%$.

0.2 is Coefficient that takes into account the wages of workers.

$\mathrm{T}_{\text {serv. }}$ - Service life of the solar station (specified in the technical data sheet) is an average of 20 years.

Annual savings for the introduction of the solar power panel [2]:

$E_{s c}=\left(E_{y r}-C_{\text {batt.p }}-M_{\text {Tex.equip }}\right)$

Where $\mathrm{E}_{\mathrm{sc}}-$ Annual electricity saving cost; $\mathrm{E}_{\mathrm{yr}}$ - annual electricity costs;

$\mathrm{C}_{\text {battp }}$ - Cost of replacement and maintenance of batteries. 
Since the service life, depending on the type of battery is from 3-5 to 10-12 years, it is necessary to take into account the cost of replacing them. For our station, a battery made using AGM technology was chosen. The life of such batteries is up to 12 years, so they will need to be completely replaced once.

\section{Annual costs of electricity supplied by a grid company [2]:}

$C_{N E P}=P_{\max } \times 365 \times C_{e e}$

$\mathrm{WhereC}_{\mathrm{ee}^{-}}$the cost of electricalenergy supplied to the establishment by a grid company, $/ \mathrm{kWh}$, (for simplification of calculations we will use the prices for a one-rate/flat rate tariff) we will accept equal $14.24 \mathrm{k} /$ $\mathrm{kWh}$ (according to the tariffs by the Power Holding Company of Nigeria (PHCN) the major electric power operating company);

$\mathrm{P}_{\max }$-Maximum power consumption, generated by an independent solar station per day, $\mathrm{kW}$.

The savings: $\mathrm{E}_{\mathrm{k}}$, from the introduction of the solar system for the year (without taking into account a one-time battery replacement):

$E_{k}=C_{\mathrm{NEP}}-M_{\text {Tex.equip }}$

Determination of the payback period $\tau$ of the event [2]:

$\tau=\frac{\frac{C_{\text {instn }}}{20}}{\mathrm{E}_{\mathrm{k}}}$

$$
\tau=\frac{\frac{5,066,344.08}{20}}{62,010}=4.1 \mathrm{yrs}
$$

\section{RESULTS AND DISCUSSION}

\section{A RESULTS}

Table 5: Cost of running the equipment

\begin{tabular}{|c|c|c|}
\hline $\mathrm{S} /$ № & ITEM & COST (N) \\
\hline 1 & 1 Generating set, $(\mathrm{dg})$ & $3,266,310.00$ \\
\hline 2 & Design, $\mathrm{C}_{\text {design }}$ & $97,989.30$ \\
\hline 3 & Installation, $\mathrm{C}_{\text {inst }}$ & $979,893.00$ \\
\hline 4 & Commissioning, $\mathrm{C}_{\mathrm{com}}$ & $130,652.40$ \\
\hline 5 & Maintenance, $\mathrm{C}_{\mathrm{mc}}$ & $326,631.00$ \\
\hline 6 & Diesel consumption & $6.21 / \mathrm{h}$ \\
\hline 7 & Diesel price, $\mathrm{F}_{\mathrm{p}}$ & $174 / l$ \\
\hline 8 & Cost of diesel, $\mathrm{F}_{\mathrm{cost}}$ & $9,450,288.00$ \\
\hline 9 & Cost of electricity, $\mathrm{C}_{\mathrm{NEP}}$ & $3,034,062.50$ \\
\hline 10 & Annual cost of running dg, $\Sigma E q$ & $4,474,844.70$ \\
\hline 11 & Annual savings for running dg, $\Delta \Sigma S$ & $-6,742,856.50$ \\
\hline
\end{tabular}

Table 6: Cost of running the Wind Power Plant

\begin{tabular}{|c|c|c|}
\hline S/№ & ITEM & COST (N) \\
\hline 1 & 1 Wind Farm, $\mathrm{C}_{\mathrm{wf}}$ & $4,350,000.00$ \\
\hline 2 & Cost of electrical equipment, $\mathrm{C}_{\text {el.eq }}$ & $2,046,500.00$ \\
\hline 3 & Cost of construction, $\mathrm{C}_{\text {const }}$ & $217,500.00$ \\
\hline 4 & Cost of commissioning, $\mathrm{C}_{\text {comm }}$ & $130,500.00$ \\
\hline 5 & Maintenance cost, $\mathrm{C}_{\mathrm{mc}}$ & 217,500 \\
\hline 6 & Total investment, $\phi_{\text {inv }}$ & $6,798,875.00$ \\
\hline 7 & Annual electricity cost, $\mathrm{C}_{\mathrm{NEP}}$ & $72,132,292.80$ \\
\hline 8 & Annual Savings, $\Delta \Sigma S$ & $71,914.79$ \\
\hline
\end{tabular}


Table 7: Cost of running the Solar Power Plant

\begin{tabular}{|c|c|c|}
\hline S/№ & ITEM & COST (N) \\
\hline 1 & Cost of installation, $\mathrm{C}_{\text {instn }}$ & $5,066,344.08$ \\
\hline 2 & Cost of commissioning, $\mathrm{K}_{\text {com }}$ & $241,254.48$ \\
\hline 3 & Maintenance cost, $\mathrm{M}_{\text {Tex.equip }}$ & $10,132.69$ \\
\hline 4 & Annual electricity cost, $\mathrm{C}_{\mathrm{NEP}}$ & $82,537.89$ \\
\hline 5 & Annual Savings, $\mathrm{E}_{\mathrm{k}}$ & $72,405.20$ \\
\hline
\end{tabular}

B DISCUSSION : Based on the data obtained in the preliminary calculations, the most cost-effective way of independent power supply is the photovoltaic station with 72,405.20k annual savings from using electricity from the national grid. This is closely followed by $71,914.79 \mathrm{k}$ by using the wind power plant. If we must improve on the power supply by the wind power plant, it will be necessary to choose a wind generator with a low starting wind speed, but with a large margin of power, which increases the cost of installation.

The annual saving for the diesel generator stands at - 6,742,856.50k; based on this result obtained, we conclude that this method of energy supply in this case is not economically feasible: the cost of fuel and maintenance significantly exceed the cost of grid electricity.

\section{Conclusion}

Three methods of energy supply for an individual residential house are considered: stations based on diesel generators, wind generators, and solar panels. Calculations of the economic feasibility of the application of the independent stations under consideration have been carried out, which have shown good efficiency for solar power plant and fairly in comparism for wind power for independent power supply in Makurdi region. The system is not economically viable for diesel generator.

\section{References:}

[1] Горшкалев, А. А. Technique of feasibility studies for the location of autonomous wind power plants, their expedient number taking into account the location on the territory of the Samara region: PhD dissertation. - Samara, 2012. - $117 \mathrm{p}$.

[2] Горяинов, С. Б. Technique of feasibility studies for the location of independent power plants, their expedient number taking into account the location on the territory of the Samara region: PhD dissertation - Samara, 2012. - $117 \mathrm{p}$.

[3] Diesel Generator SDMO K27 // Generator-Pro URL: http://generator-pro.ru/catalog/sdmo/sdmo-k27 (reference date: 23.10 .2016 ).

[4] Иванчура, В. И., ЧубарьА. В. Energy Models of Elements of Independent Power Systems // Institute of Space and Information Technologies of the Siberian Federal University. - 2012. - No. 4. - P. 179-190.

[5] Inverter MAP SIN Energy Pro 48V $6 \mathrm{~kW} / /$ MicroART URL: http://invertor.ru/zzz/item/map_sin_pro_48_6 (reference date: 30.10.2016).

[6] Solar installations // Perpetuum mobile URL: http://khd2.narod.ru/gratis/solar.htm\#EMISSION (reference date: 06.10.2016).

[7] Traction armor batteries of deep discharge, for stand-alone and backup systems. // Microart URL: http://invertor.ru/zzz/item/2_960 (date of circulation: 30.10 .2016 ).

[8] A. Mellit, M. Benghanem, and M. Bendekhis, "Artificial neural network model for prediction solar radiation data: application for sizing stand-alone photovoltaic power system," in Proceedings of the IEEE Power Engineering Society General Meeting, vol. 1, pp. 40-44, June 2005. View at Publisher View at Google Scholar · View at Scopus

[9] M. Engin, "Sizing and simulation of PV-wind hybrid power system," International Journal of Photoenergy, vol. 2013, Article ID 217526, 10 pages, 2013. View at Publisher · View at Google Scholar

[10] R. S. Eckman and P. W. Stackhouse Jr., "CEOS contributions to informing energy management and policy decision making using space-based Earth observations,"Applied Energy, vol. 90, no. 1, pp. 206-210, 2012. View at Publisher · View at Google Scholar · View at Scopus 